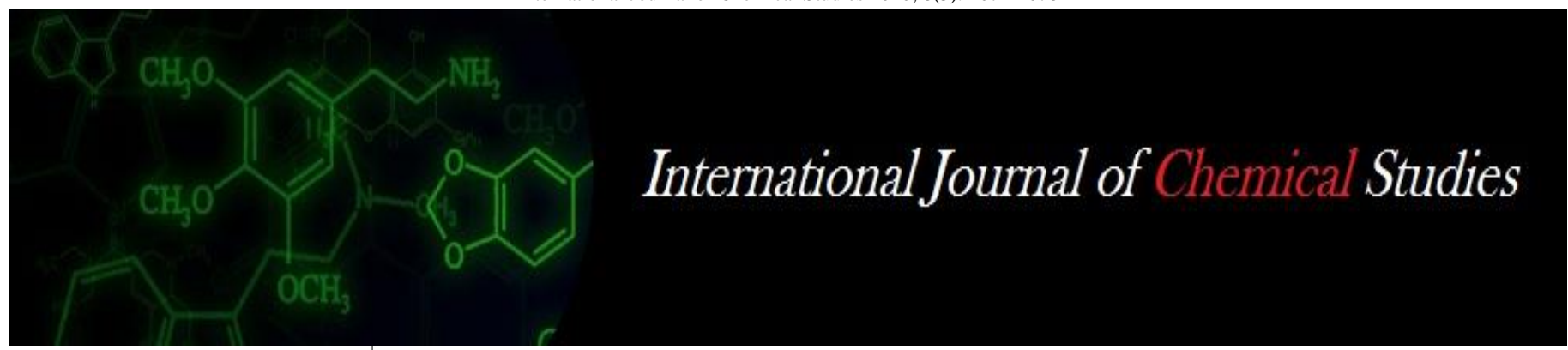

P-ISSN: 2349-8528

E-ISSN: 2321-4902

www.chemijournal.com

IJCS 2020; 8(3): 1071-1078

(C) 2020 IJCS

Received: 13-03-2020

Accepted: 15-04-2020

\section{Manju Lata}

Department of Biosciences, MLSM College Sunder Nagar, District Mandi, Himachal

Pradesh, India
Corresponding Author: Manju Lata

Department of Biosciences, MLSM College Sunder Nagar, District Mandi, Himachal Pradesh, India

\section{An ethnobotanical survey of medicinal plants used by tribal migratory shepherds in hills of Tungasigarh of Thunag Subdivision of district Mandi Himachal Pradesh}

\section{Manju Lata}

DOI: https://doi.org/10.22271/chemi.2020.v8.i3n.9341

\begin{abstract}
In Himachal Pradesh tribal migratory shepherds carry rich repository of traditional knowledge of wild medicinal plants and its uses, in this respect, an ethnobotanical survey was carried out in Tungasigarh and its surrounding area of Thunag Subdivision district Mandi Himachal Pradesh from 2018 to 2019. The required information on ethnomedicines used by tribal migratory shepherds was collected through personal field visits, interview method and by using a pretested questionnaire. Total 64 medicinal plant species were reported viz. Aconitum heterophyllum Allium ursinum, Allium humile, Trillium govaninum, Bergenia ciliata, Berberis lyceum, Cannabis sativa, Dioscrea deltoidea, Rhododendron arboratum, Pistacia integerrima, Zanthoxylem armatum was recorded. Total of 64 species were documented herb species were dominant (48) followed by shrub (9), tree (7). This study shows that shepherds in tribal areas are highly dependent on ethnobotanical medicines, which evolved over generations of experience, for the healthcare. This survey can help as baseline data on ethnomedicinal plants used in Thunag sub division of Mandi district and could be helpful in conservation of traditional knowledge as well as medicinal plants.
\end{abstract}

Keywords: Tungasigarh, Thunag, migratory shepherd, ethnomedicinal, Mandi, North Western Himalaya

\section{Introduction}

In India, it has been reported that about $90-95 \%$ collection of medicinal plants is collected from the wild area (Adhikari et al., 2010) ${ }^{[1]}$. The Indian Himalayan region is characterized by its unique ecosystem with a wide range of climates and habitat types which supports different flora and fauna. The Himalaya Hotspot is home to the world's highest mountains. The mountains of Himalaya rise abruptly, resulting in a variety of ecosystems. Himachal Pradesh, a North Indian state, is located in the western part of the Himalaya. The state has a wide geographical area $(55,673 \mathrm{~km} 2)$ and altitudinal variation $(350-7000 \mathrm{~m} \mathrm{amsl})$ with a rich assortment of biotic components. Himachal Pradesh has a forest cover of $27.72 \%$ and rich in medicinal plant species. The plant medications of inhabitants, handed down by word of mouth from one generation to the next generation, gradually became part of the knowledge of ancient civilization. Majority of the rural societies possess significant traditional knowledge of natural resources, which they have inherited from their forefather. Since long time traditional knowledge of ethnomedicines are used by our ancestors for their well-being and transferred orally to next generation (Sharma and Rana, 2016) ${ }^{[12]}$. Ethnobotanical work in different parts of Himachal Pradesh had been conducted by many workers (Dutt et al., 2014) ${ }^{[8]}$. Moreover, Himachal Pradesh has led to tribal ways of life, adherence to the primitive customs and traditions representing on enormous and difficult terrain of scattered human settlement (Chowdhery, 1999) ${ }^{[7]}$. Majority of the rural societies depend on this traditional knowledge for a variety of reasons related to the healthcare, social order, economy, shelter and food etc. Attention in herbal medicines has increased considerably as they are believed to be comparatively less toxic than the synthetic drugs and easily available from surroundings without any cost. The Migratory shepherds also take along with them few horses for carrying eatables and shelters. Often 4-5 dogs also accompany the migratory shepherds and, these dogs 
are very well trained in protecting their livestock from wild animal attacks They closely depend on this knowledge for a variety of reasons related to the social order, health care, economy, shelter, food, etc. However, if the efforts are not made with instant effect, the rich traditional knowledge possessed by these semipastoral shephards communities will vanish soon. This calls for an urgent need to document ethnomedicinal plant species of this area.

\section{Material and Method}

Study area: Himachal Pradesh $\left(30^{\circ} 22^{\prime} 40^{\prime \prime}\right.$ to $30^{\circ} 12^{\prime} 40^{\prime \prime} \mathrm{N}$ latitudes and $75^{\circ} 47^{\prime} 55^{\prime \prime}$ to $79^{\circ} 04^{\prime} 20^{\prime \prime}$ E longitudes) is a North western Himalayan state of India which is a rich repository of ethnomedicinal flora. Most of these plant species find their use in traditional medicine, folk uses and also in modern industry (Singh and Thakur, 2014).Present study was carried out in the Tungasigarh area $(3500 \mathrm{~m})$ of Thunag sub division $\left(31.55^{\circ} \mathrm{N}, 77.17^{\circ} \mathrm{E}\right)$ at an altitude of $2052 \mathrm{~m}$, of district Mandi $\left(31.5892^{\circ} \mathrm{N}, 76.9182^{\circ} \mathrm{E}\right)$ Himachal Pradesh. The area is covered by dense forest of conifers and oak trees. This area is rich in medicinal flora and is having meadows which offer suitable site to perform the routine work for shephards. Soil is fertile and rich in humus and nitrogenous compounds but lacks phosphate compounds. The major soil groups are brown hill soil and red loamy soil. Most soil in this region are acidic in nature. Being a hilly valley climate is cool and temperate with three distinct season; the winter (October to March), the summer (April to june), the moonson (July to September). Highest temperature is recorded during May and June varying between 30 to 35 . Lowest temperature is recorded during December and January month. The annual rainfall is around $1240 \mathrm{~mm}$.

\section{Method}

The important biodiversity of medicinal plants of Tungasigarh area of Thunag sub division was surveyed. For this survey, field trips of the entire area was undertaken between 2018 to 2019. The information on wild medicinal plants used by tribal migratory shepherds in this area was collected by using pretested questionnaire, participatory observation, interviews and through discussion method. The fast acceleration of market pressure for medicinal plants, and recent disputes related to benefit sharing, the proper documentation of traditional knowledge is of vital priority (Singh and Batish, 2015; Yadav et al., 2014) $\left[17,{ }^{19]}\right.$. The continuation of traditional knowledge is risking as the transmission between the younger and older generations no longer exists (Kapoor, 2017) ${ }^{[11]}$. Therefore, proper documentation of the traditional information through ethnobotanical studies is significant for the utilization of biological resources and their conservation (Bagga et al., 2018) ${ }^{[4]}$. Difficult environmental conditions cause seasonal migration of shepherds from high hills to low hills in different parts of Himachal Pradesh. In the tribes of Himalayan region seasonal migration is a traditional process. It was notable that migration patterns of shepherds closely mirror the seasonal availability of natural fodder (Rao et al., 2011).These semipastoral shepherd carry along with them rich knowledge of traditional medicinal plants. But unfortunately there is no written documentation of ethnomedicinal plants used by shepherds in the Tungasigarh area inspite of frequent migration of shepherds. The traditional knowledge, plant biodiversity, and cultural practices of the tribal people are facing high threat due to fast urbanization.

Table 1: List of Ethnomedicinal plants used by semipastoral shepherd community.

\begin{tabular}{|c|c|c|c|c|}
\hline $\begin{array}{l}\text { S. } \\
\text { No. }\end{array}$ & Groups/Family/Plant species & $\begin{array}{l}\text { Vernacular } \\
\text { name }\end{array}$ & Habit & Ethnomedicinal properties \\
\hline 1. & $\begin{array}{l}\text { Fungi/Morchellaceae } \\
\text { Morchella esculenta }\end{array}$ & Dunglu/ Guchhi & Herbs & $\begin{array}{c}\text { Antioxidant, liver protection, edible, } \\
\text { exhibit carcinogenic properties. }\end{array}$ \\
\hline 2 & $\begin{array}{l}\text { Discinaceae } \\
\text { Gyromitra esculenta }\end{array}$ & Ban dunglu & Herbs & Edible, antioxidant, exhibit carcinogenic properties. \\
\hline 3. & $\begin{array}{l}\text { Pteridophytes/Adiantaceae } \\
\text { Adiantum capillus }\end{array}$ & Barin & Herb & Cough, fever, menstrual problems, bronchitis. \\
\hline 4. & Equisetaceae/Equisetum arvense & - & Herb & Diuretic, dyspepsia \\
\hline 5. & $\begin{array}{l}\text { Gymnosperm/Pinaceae/ } \\
\text { Cedrus deodara }\end{array}$ & Dair & Tree & Ulcer, rheumatisim, fuel and timber. \\
\hline 6. & Pinus wallichiana & Kail,Bluepine & Tree & Treat wounds, sores, burns, boils, ulcer. \\
\hline 7. & Pinus roxburghii & Chir & Tree & Medicinal (Bone fracture, sprain, swelling, skin diseases, snake bite) \\
\hline 8. & Taxaceae /Taxus baccata & Rakhal & Tree & Beverages, treat asthma, bronchitis and bone fracture. \\
\hline 9. & Angiosperm/Alliaceae/Allium humile & Lahne & Herb & Stomachache, asthma, cold and cough. Edible. \\
\hline 10. & Allium ursanium & Jangli lahasun & Herb & Stomachic, infusion used against worms. Edible used as spice. \\
\hline 11. & $\begin{array}{l}\text { Angiosperms/ Amaranthaceae } \\
\text { Achyranthes aspera }\end{array}$ & Putkanda & Herb & Bronchitis, asthma, dysentery, cold, cough, stomachache. \\
\hline 12. & Anacardiaceae/ Pistacia integerrima & Kakar singhi & Tree & Cough, asthma, fever, appetite, pulmonary infection. \\
\hline 13. & Apiaceae/Angelica glauca & Chora & Herb & Dyspepsia, dysentery, ulcer, gastric pain. \\
\hline 14. & Heracleum candicans & Badiyacha & Herb & Leucoderma and menstrual complaints \\
\hline 15. & Selinium tenuifolium & Bhutkeshi & Herb & Nervine tonic, sedative \\
\hline 16. & Asteraceae/ Achilea milefolium & Fye & Herb & Cold, fever, epilepsy, gastric complaints, piles, stimulant. \\
\hline 17. & Ainsliaea aptera & Satjalari & Herb & Stomach \\
\hline 18. & Artemisia nilagirica & Kubsh & Herb & $\begin{array}{c}\text { Analgesic, antiseptic, asthma, headache, nervous disorder, skin disease, } \\
\text { sores wounds. }\end{array}$ \\
\hline 19. & Bidens pilosa & Bhatkumbal & Herb & Cough cut ear and eye complaints, headache, leprosy, skin disease. \\
\hline 20. & Cirsium wallichii & Bhrsha & Herb & Swelling, headache and pneumonia. \\
\hline 21. & Senecio graciflorus & & Herb & Insect bite, ringworm disease and ear ache. \\
\hline 22. & Sonchus asper & & Herb & Cuts and injuries \\
\hline 23. & Taraxacum officinalies & Gahri phul & Herb & Blister, antioxidants, kidney diseases liver complaints, wounds. \\
\hline 24. & Begoniaceae/Begonia picta & & Herb & Mouth ulcer, tounge bristle. \\
\hline
\end{tabular}




\begin{tabular}{|c|c|c|c|c|}
\hline 25. & Berberidaceae/ Berberis aristata & Kashmal & shrub & Malaria, piles, antitode to snake bite. \\
\hline 26. & Berberis lyceum & Kashmal & shrub & Eye disease, jaundice. \\
\hline 27. & Betulaceae/Alnus nitida & Kosh & Tree & Cuts, wounds and stomachache \\
\hline 28. & Brassicaceae/Nasturtium officinale & Chuch & Herb & Kidney complaints, inflammation of skin, hypoglycaemic. \\
\hline 29. & Cannabaceae/ Cannabis sativa & Bhang/bijay & Herb & $\begin{array}{l}\text { Nervine stimulant, piles, skin diseases, cuts, dyspepsia, cramps. appetizer, } \\
\text { sleep pills. }\end{array}$ \\
\hline 30. & Caryophyllaceae/ Silene media & Bariyala & Herb & Bone fracture \\
\hline 31. & Celastraceae/ Euonymus pendulus & Chopru & Tree & Dysentry, eye disease and headache. \\
\hline 32. & Chenopodiaceae/ Chenopodium album & Bithu & Herb & Skin disease, uterine complaint. \\
\hline 33. & $\begin{array}{l}\text { Cucurbitaceae/ Trichosanthes } \\
\text { tricuspidata }\end{array}$ & & Herb & Burns, diarrhoea, rheumatism, snake bite and vomiting. \\
\hline 34. & Dioscoreaceae/ Dioscorea deltoidea & & Herb & Dysentery and pile. \\
\hline 35. & Morinaceae/Morina longifolia & & Herb & Boils \\
\hline 36. & Fabeceae/Desmodium elegans & Kathi & shrub & Carminative, epilepsy \\
\hline 37. & Indigofera heterantha & Kali kathi & shrub & Veterinary disease urinary problems. \\
\hline 38. & Trifolium repens & Tin pati & Herb & Astringent \\
\hline 39. & Vigna vaxillata & & Herb & Cholera and ulcer \\
\hline 40. & Hypericaceae/ Hypericum japonicum & & Herb & Skin diseases \\
\hline 41. & H. oblongifolium & Kharau & Shrub & Wounds and boils \\
\hline 42. & H. uralum & Bani wakra & shrub & Food poisoning. \\
\hline 43. & Lamiaceae/Ajuga bracteosa & Neel kanth & Herb & Root for diarrhoea and dysentery, ascariasis, fever \\
\hline 44. & Clinopodium umbrosum & & Herb & Astrigent, Carminative and Heart Tonic \\
\hline 45. & Origanatum vulgare & Bantulsi & Herb & Cold, fever, hysteria, influenza, stimulant, tonic. \\
\hline 46. & Plectranthus coesta & Chichri & Herb & Gastric complaint. \\
\hline 47. & Thymus linearis & Madroshda & Herb & Stomach ache, vermicidal, liver complaint, eye disorder. \\
\hline 48 & Liliaceae/Polygonatum cirrhifolium & Salam Mishri & Herb & Appetite, nervine tonic, Edible. \\
\hline 49. & Cardiocrinum gigantum & & Herb & $\begin{array}{l}\text { Leaves for wounds, bruises. } \\
\text { Paste of roots applied for bone fracture. }\end{array}$ \\
\hline 50. & Loranthaceae/Viscaceae album & Rhini & shrub & Abortifacient, antifertility, bodyache. \\
\hline 51. & Malvaceae/Malva verticillata & Sochali & Herb & Cough, piles, ulcer and urine complaint. \\
\hline 52. & Melanthiaceae/Trillium govanianum & Nagchatri & Herb & $\begin{array}{l}\text { Used to treat boils, dysentery, menstrual and sexual disorders, antiseptic } \\
\text { and wound healing. }\end{array}$ \\
\hline 53. & Oleaceae/Jasminum & Banmalti & Shrub & Skin disease, blood disease, and heart problem. \\
\hline 54. & $\begin{array}{l}\text { Podophyllllaceae/Podophyllum } \\
\text { hexandrum }\end{array}$ & Ban kakri & Herb & Cancer, cough, cuts wounds, fever, gastric ulcers, liver diseases. \\
\hline 55. & Polygonaceae/Fagopyrum dibotrys & Fafra & Herb & Insect bite \\
\hline 56. & Fagopyrum esculentum & Kathu & Herb & Typhoid, Lung disorder, urine complaint. \\
\hline 57. & Ranunculaceae/Aconitum heterophyllum & Patish & Herb & Dyspepsia, diarrhoea, cough \\
\hline 58. & Rosaceae/Agrimonia pilosa & Kanaula & Herb & Cough and urinary problem. \\
\hline 59. & Principia utilis & Bekhal & shrub & Burns, cuts, wounds. \\
\hline 60. & Urticaceae/Urtica dioica & Kugas & Herb & Antiseptic, dandruff and swelling \\
\hline 61. & Valerianaceae/ Valeriana jatamansi & Nihani & Herb & Antidote to sting of insect, hysteria, neurosis and skin diseases. \\
\hline 62. & Violaceae Viola pilosa & Banaksha & Herb & Cough, cold, fever and lung disease. \\
\hline 63. & Viola biflora & Banaksha & Herb & Bronchitis, cold and cough. \\
\hline 64. & Zingiberaceae/ Hedychium spicatum & Ban haldi & Herb & Asthma, bronchitis vomiting, dyspepsia. \\
\hline
\end{tabular}

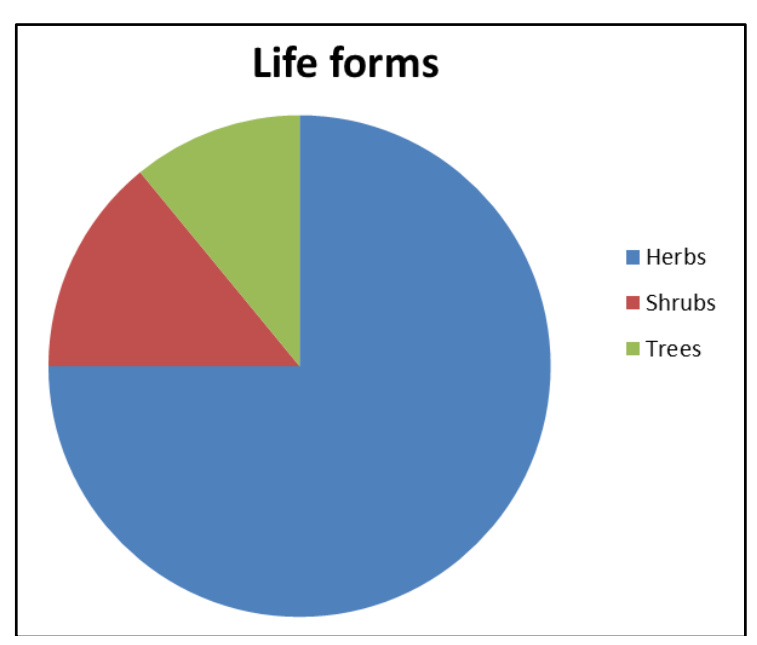

Pie chart 1: depecting the life forms of study area: Herbs; 75\%, Shrubs ; $14 \%$,Trees $; 11 \%$

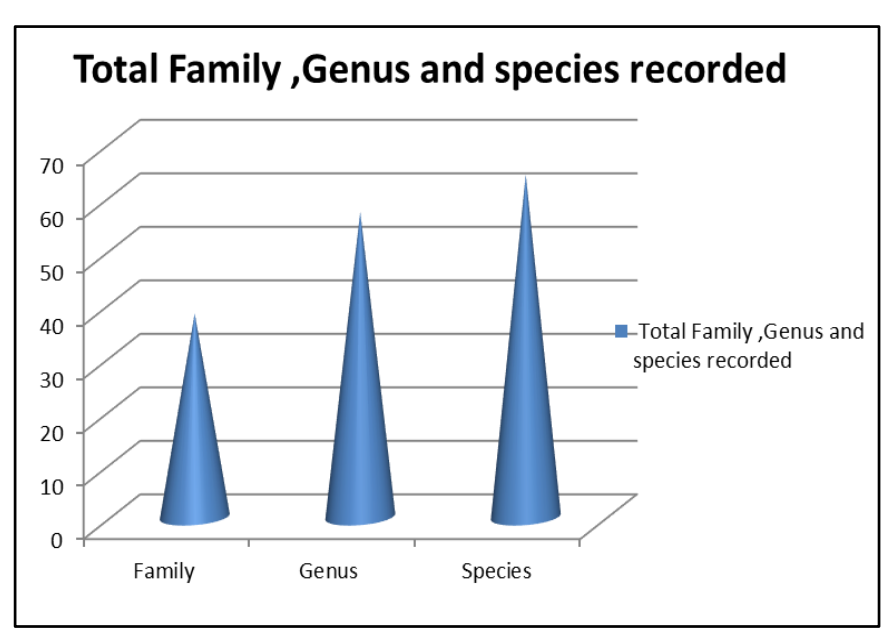

Pie chart 2: Family 38, Genus: 57, Species: 64. 


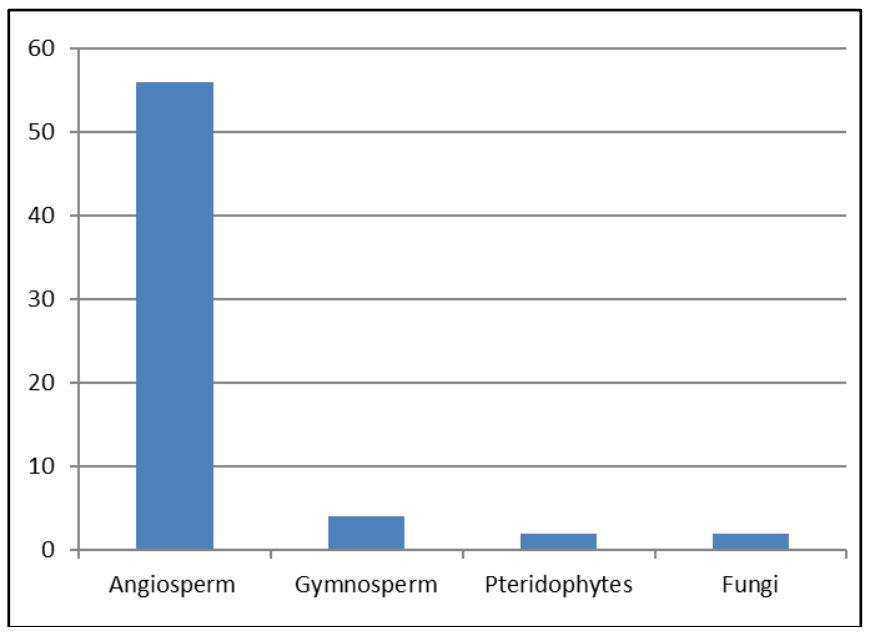

Pie chart 3: Histogram showing the documentation of different categories of flora from study area

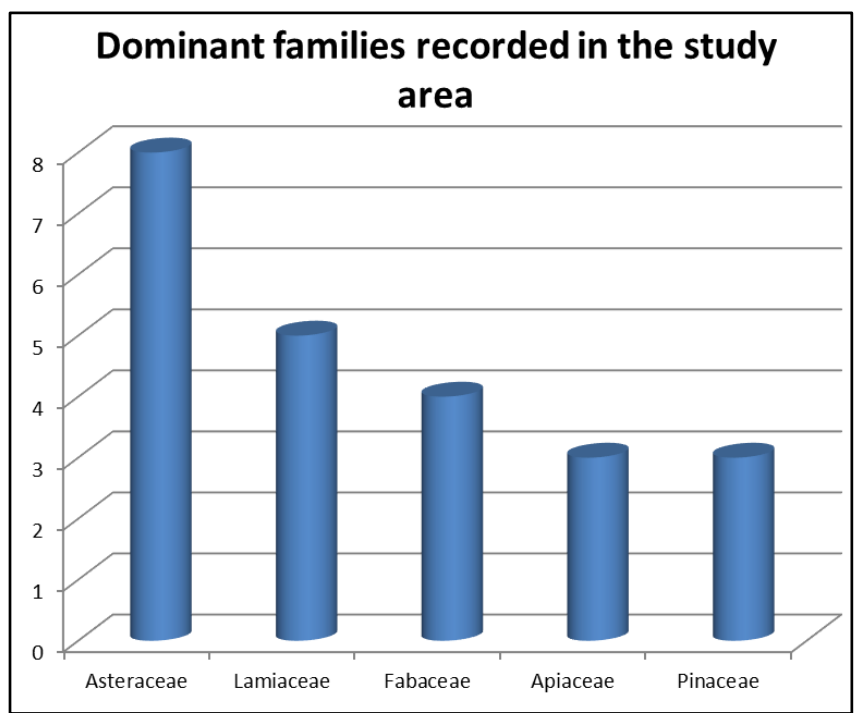

Pie chart 4: Histogram showing dominant families

\section{Results}

The present study was carried out in the Tungasigarh area of Thunag subdivision of district Mandi Himachal Pradesh. Documentation of the ethnomedicinal plants used by the semipastoral shephards community was done. Concerning the ethnomedicines used by migratory shepherds in their own traditional health care system. A total of 64 ethnomedicinal plants were documented in study area. It was recorded that herb species were markedly high (48) followed by shrub (9), tree (7). Among these medicinal plant species, the maximum medicinal plants were used for cough, cold, skin, stomachache, cuts and wound healing etc.

Shephards are much dependant on forest produce for their requirement of fruits, vegetables and medicines. The fast acceleration of market pressure for medicinal plants, and recent disputes related to benefit sharing, the proper documentation of traditional knowledge is of vital priority (Singh and Batish, 2015; Yadav et al., 2014) ${ }^{[17,19]}$. The continuation of traditional knowledge is risking as the transmission between the younger and older generations no longer exists (Kapoor, 2017) [11]. Therefore, proper documentation of the traditional information through ethnobotanical studies is significant for the utilization of biological resources and their conservation (Bagga et al., 2018) ${ }^{[4]}$. Unluckily, over exploitation of medicinal plants and the changing environmental conditions have made accessibility of medicinal plants as a scarce resource to the migratory shepherds during their seasonal migration. It is also highlighted that satisfactory attention has not been put in promoting and conserving traditional used medicinal plants. There is an urgent need to adopt large scale plantation of these medicinal plant species within the forests and roadsides so that the tribal shepherds are profited. It can be concluded that documentation of this traditional knowledge is novel information from the area of Thunag subdivision district Mandi, Himachal Pradesh.

\section{Conclusion}

Present study is the first attempt of survey in Tungasigarh area of Thunag subdivision of Mandi district, Himachal Pradesh, India. Dominant families recorded in the study areas were Asteraceae, Lamiaceae, Fabaceae, Apiaceae, Pinaceae. Angelica glauca, Allium ursanium, Hedychium spicatum, Viola specie, Trillium govanianum are well known medicinal plant species, used by shephards and by local inhabitants contributing important role in the local health care system. Documentation of local medicinal knowledge is also essential due to outmigration of the younger. Study of ethnomedicinal knowledge helps identify the important species of the region for pharmacological importance and ecological sustainability and it also aids conservation of traditional knowledge. Migratory shepherds a tribal community of Western Himalaya were identified. They are using the plants for cough, cold, fever, stomachache, asthma, skin allergy, bone fracture, abdominal pain, jaundice, body pain, bone fracture, malaria, wound healing, tonic, etc., in various forms such as decoction, powder, paste, and juice. The foremost important thing is to give awareness and training to tribal migratory shepherds on a multidimensional basis about sustainable utilization of wild medicinal plant wealth in the hillside management for plant resources. This valuable survey may be useful to improve the pharmaceutical and application in the future.

\section{Acknowledgement}

Author is thankful to Forest Department, migratory shephards and inhabitants of the area for their kind help and providing valuable information during the field surveys. 

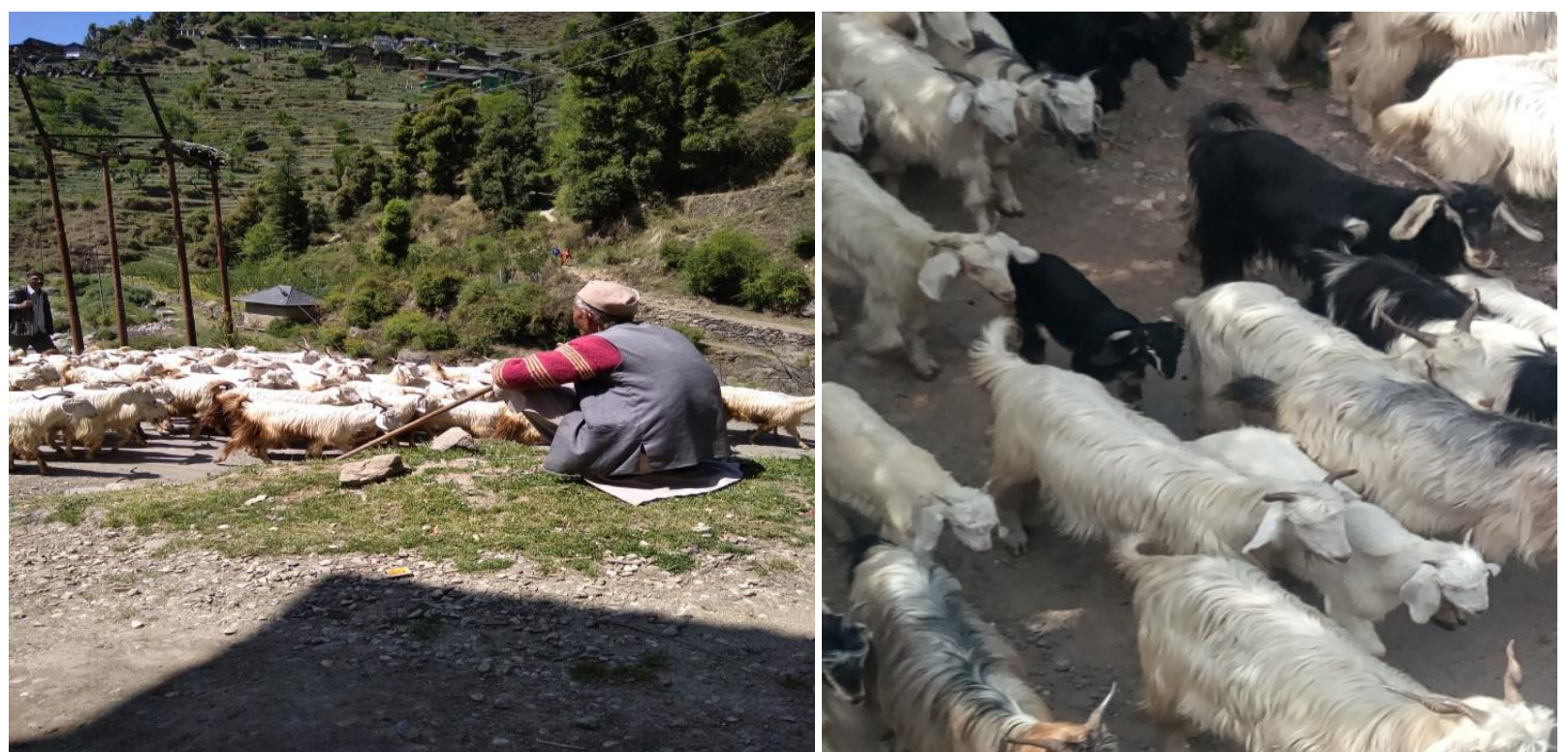

Shephard about to reach in the valley

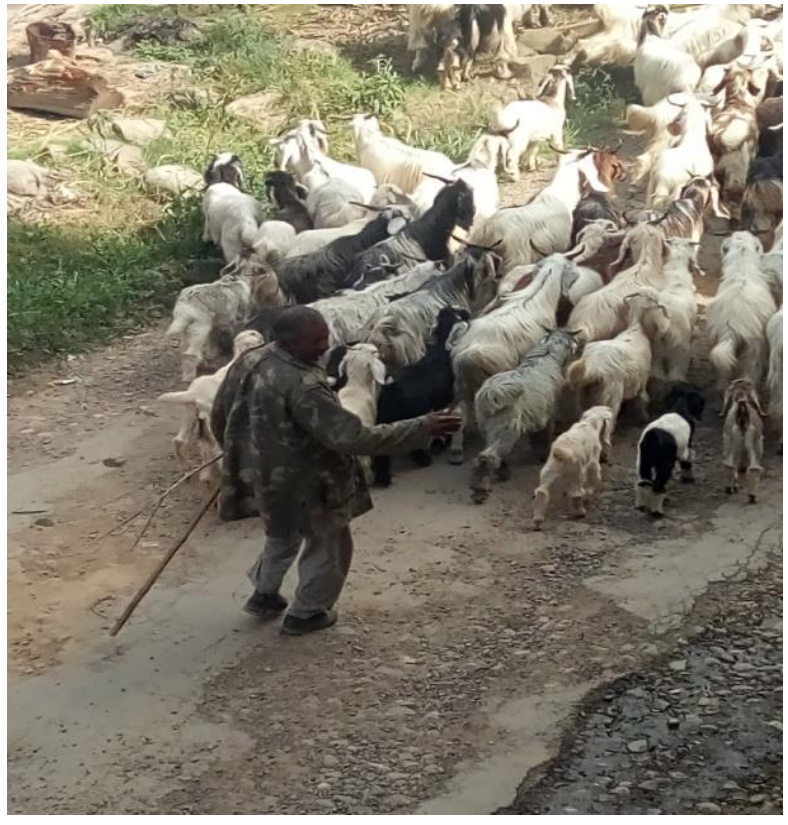

Goat flocks being directed by shepherds

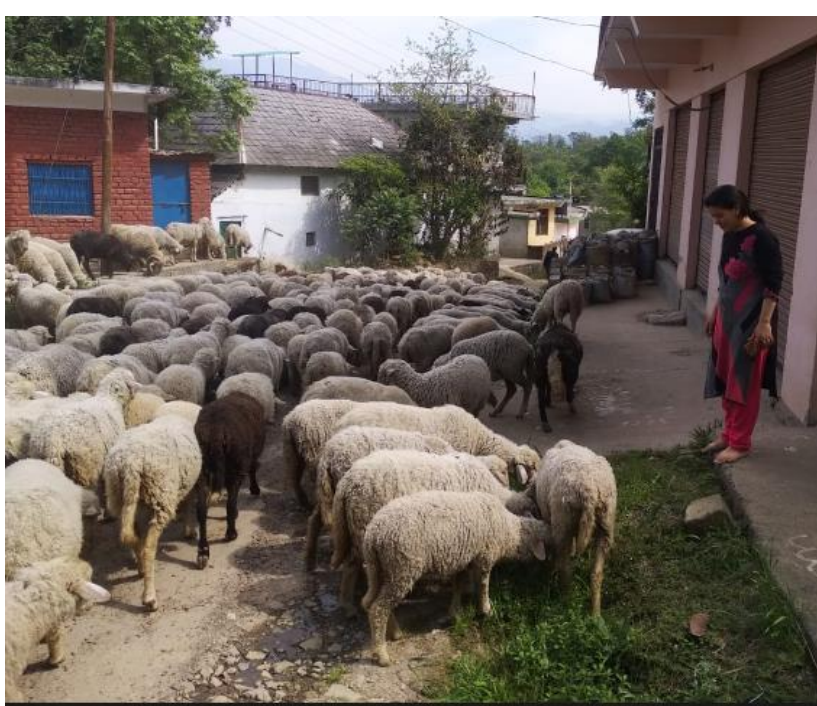

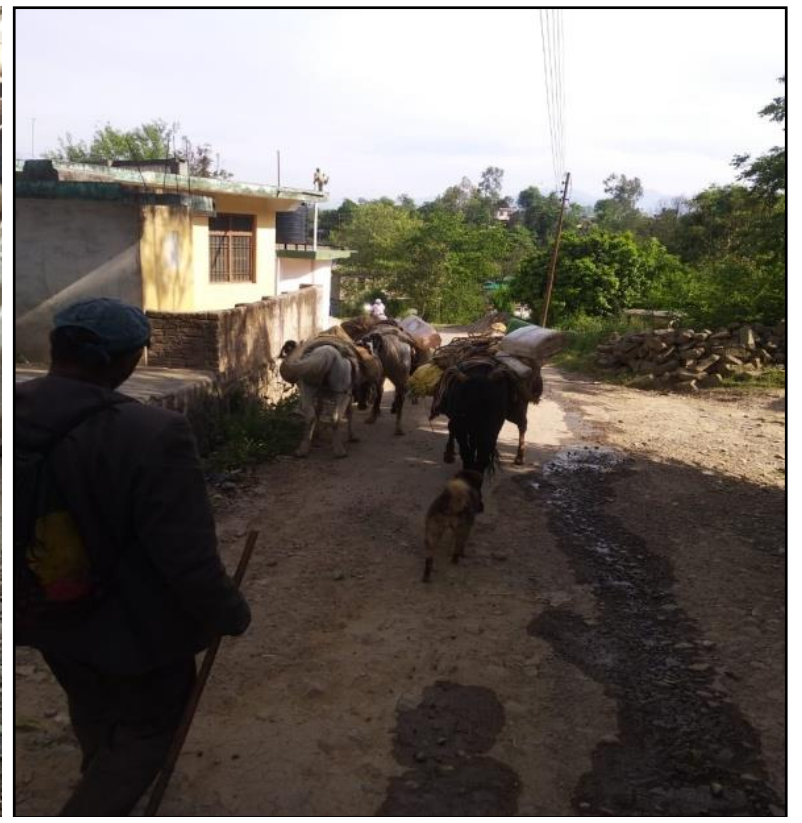

Horses and dogs parts of their herds

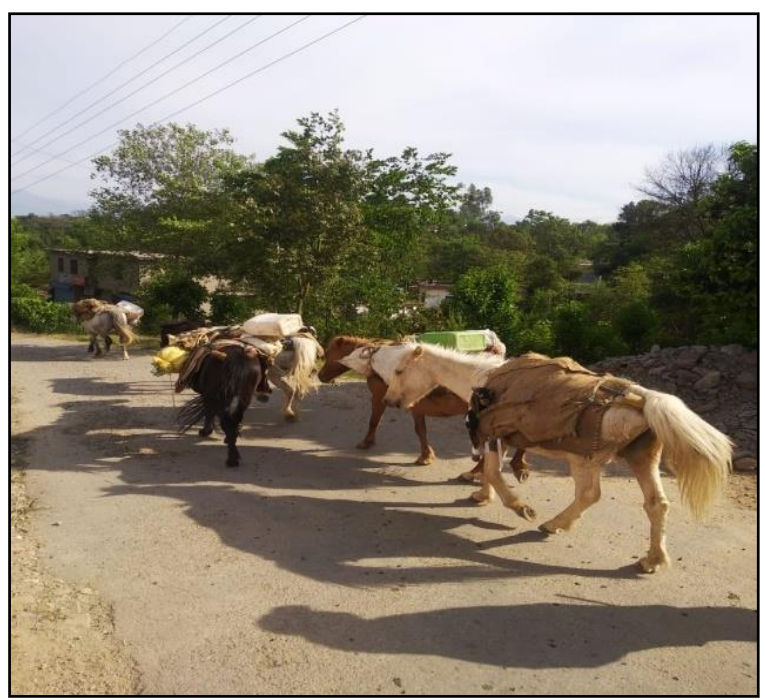

Shephards on the way towards their destination from plains to hilly region along with stud of horses. 


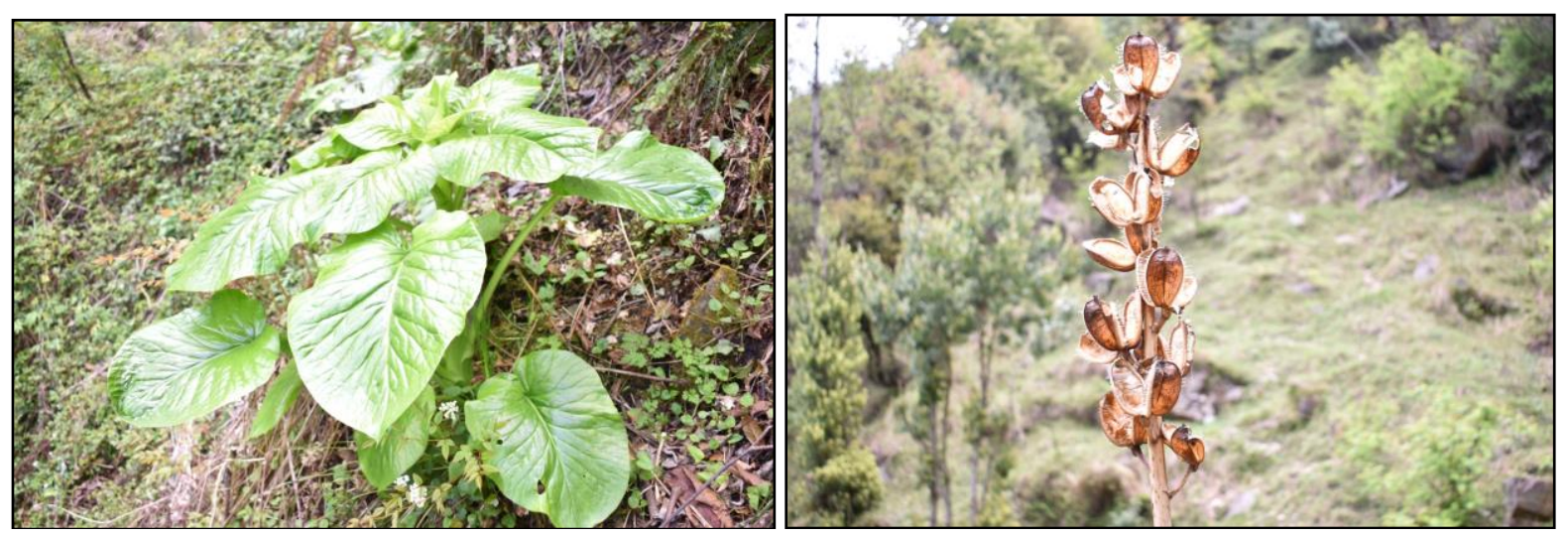

Cardiocrinum giganteum plant and seedcases

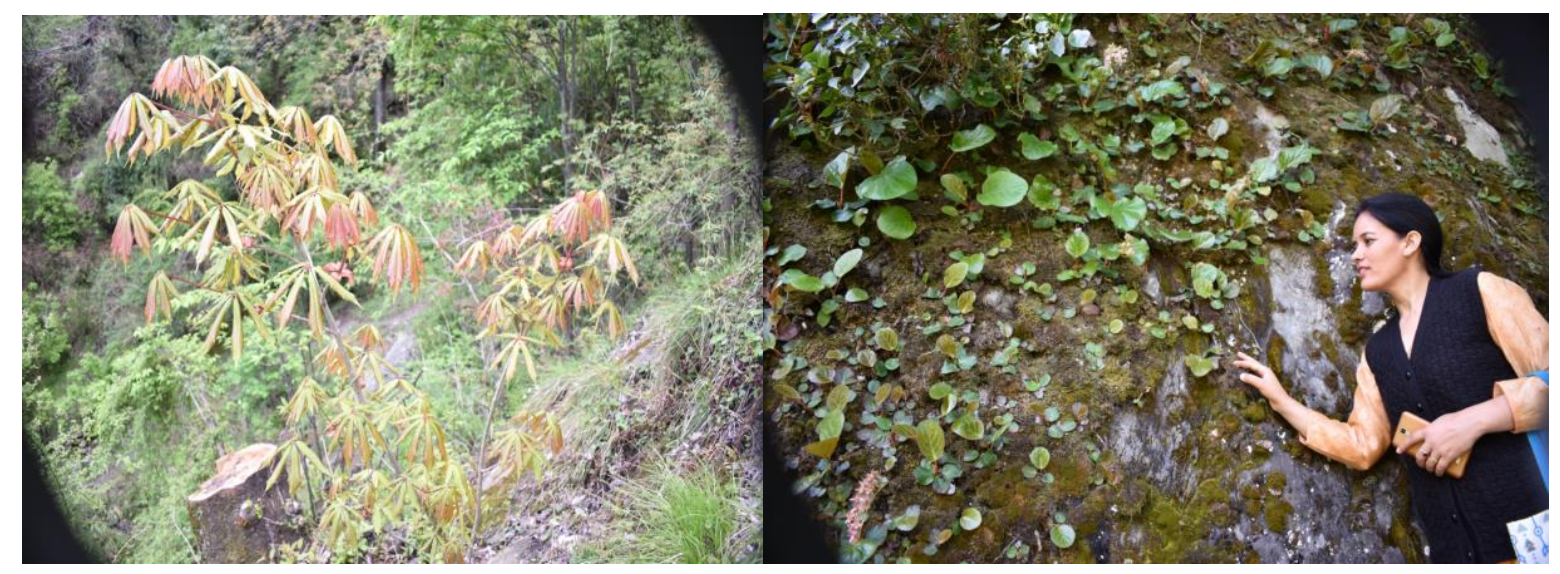

Aesculus indica

Bergenia ciliata

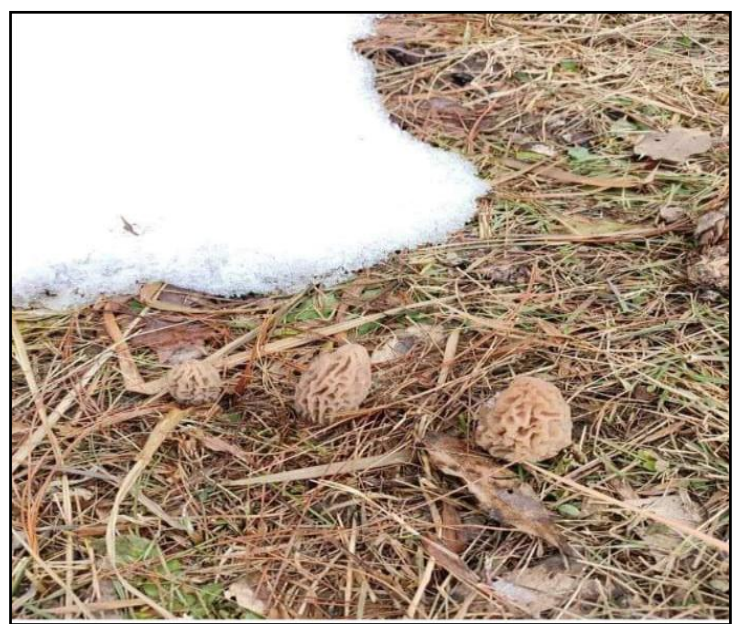

Morchella esculenta

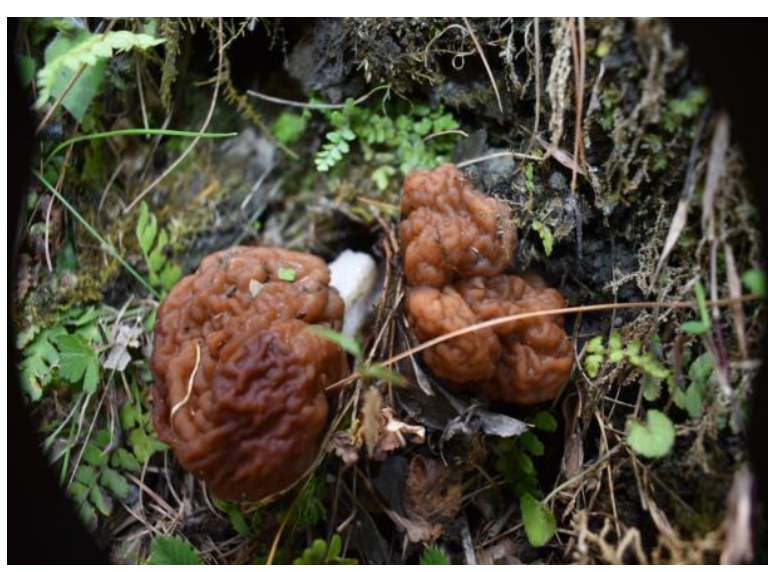

Gyrometra esculenta

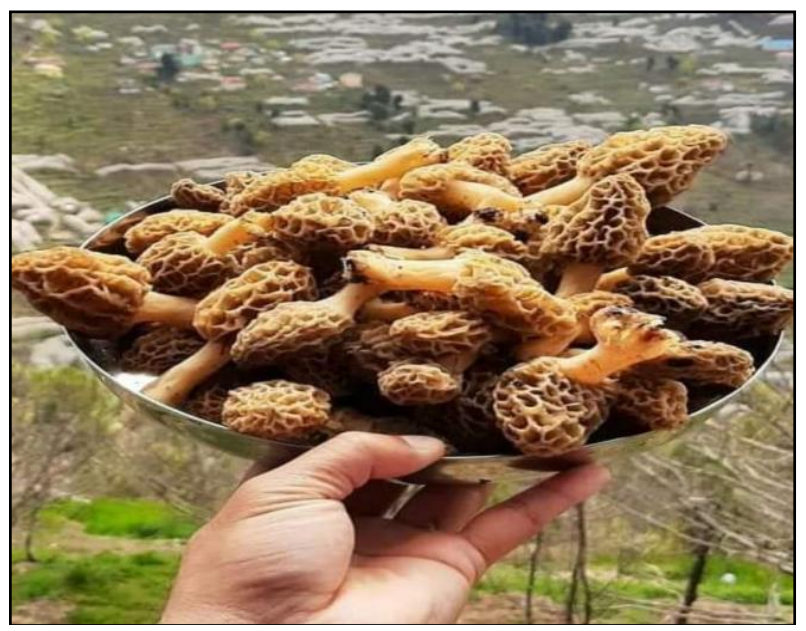

Harvested Morchella esculenta.

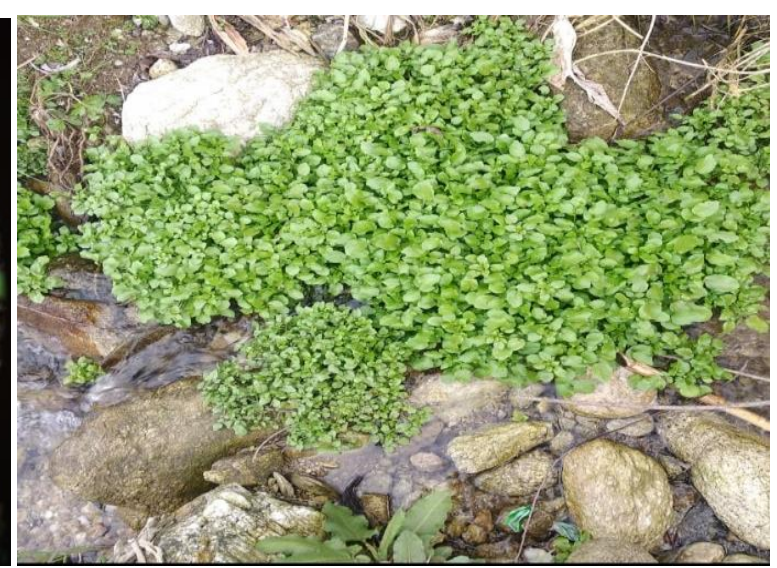

Naustratium officinale 


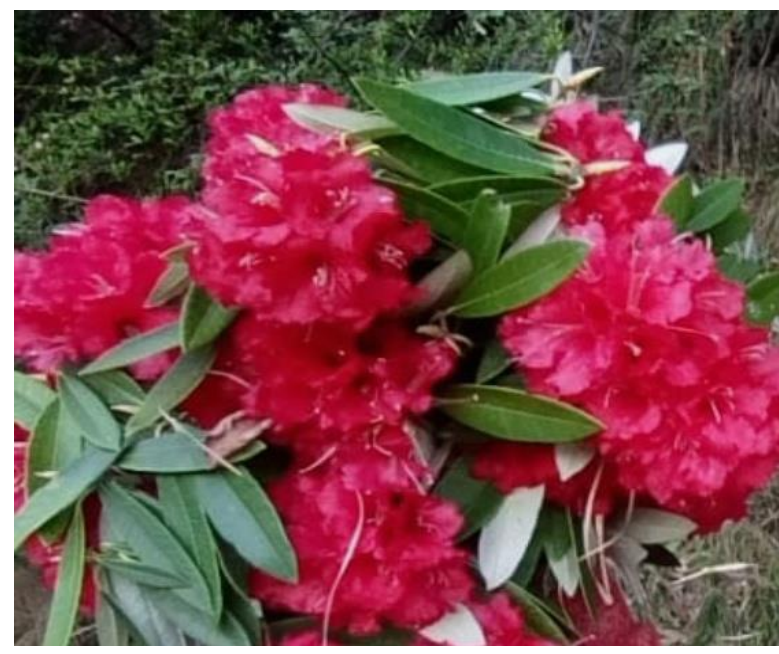

Rhododendron arboratum

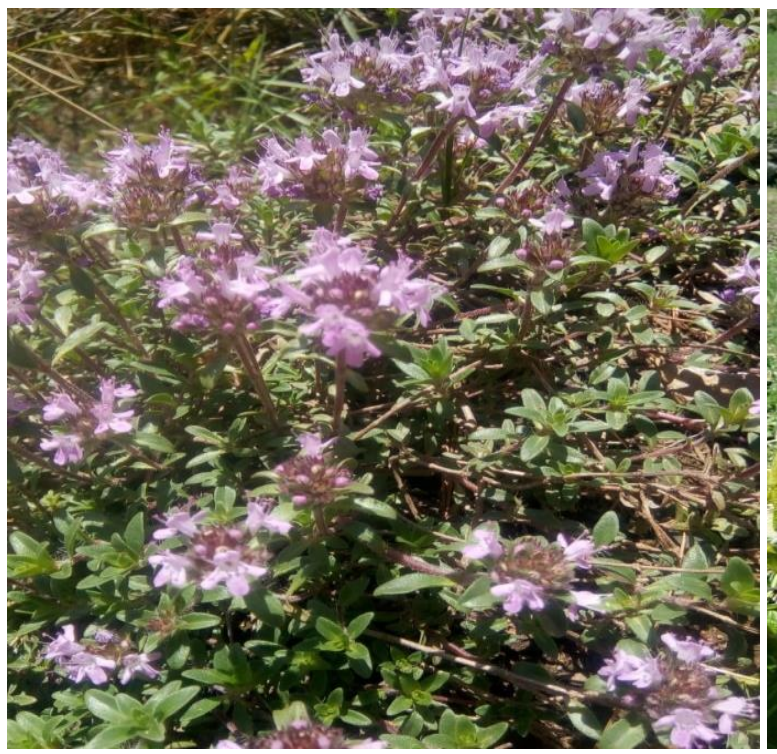

Thymus linearis

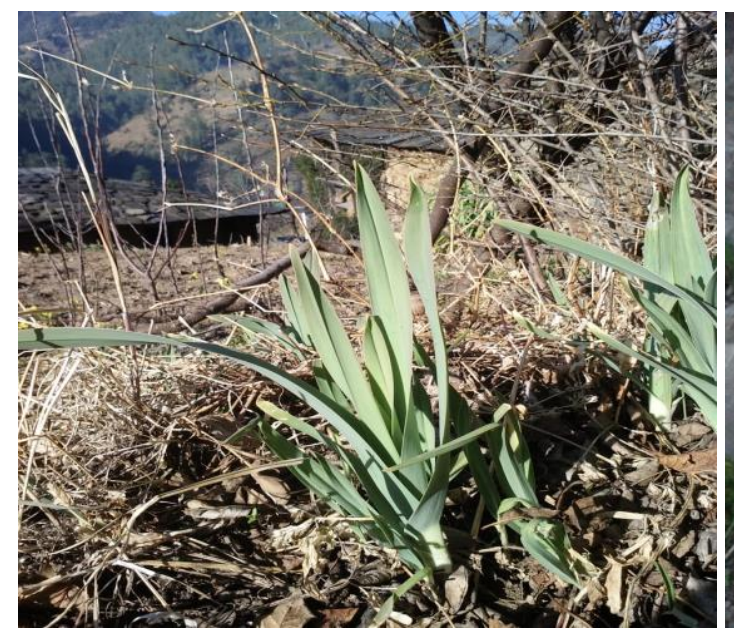

Allium humile

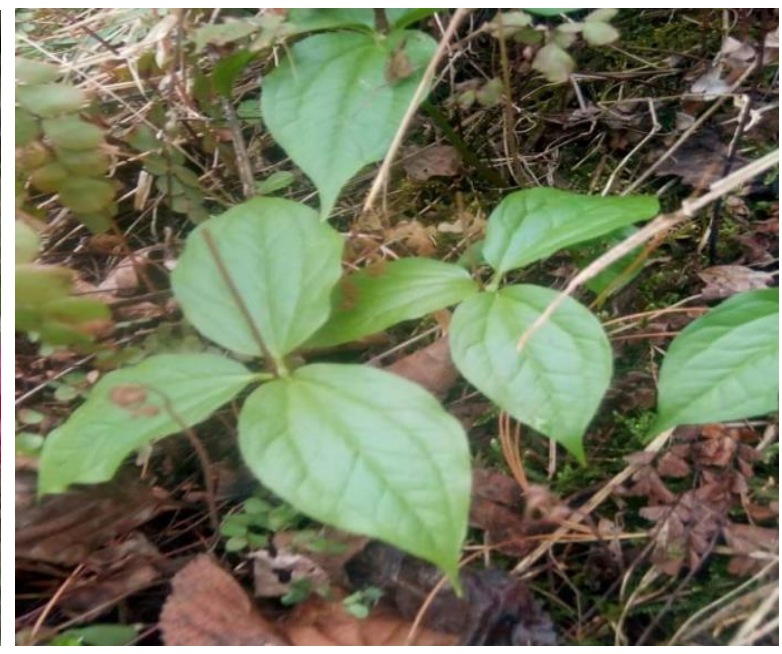

Trillium govanianum

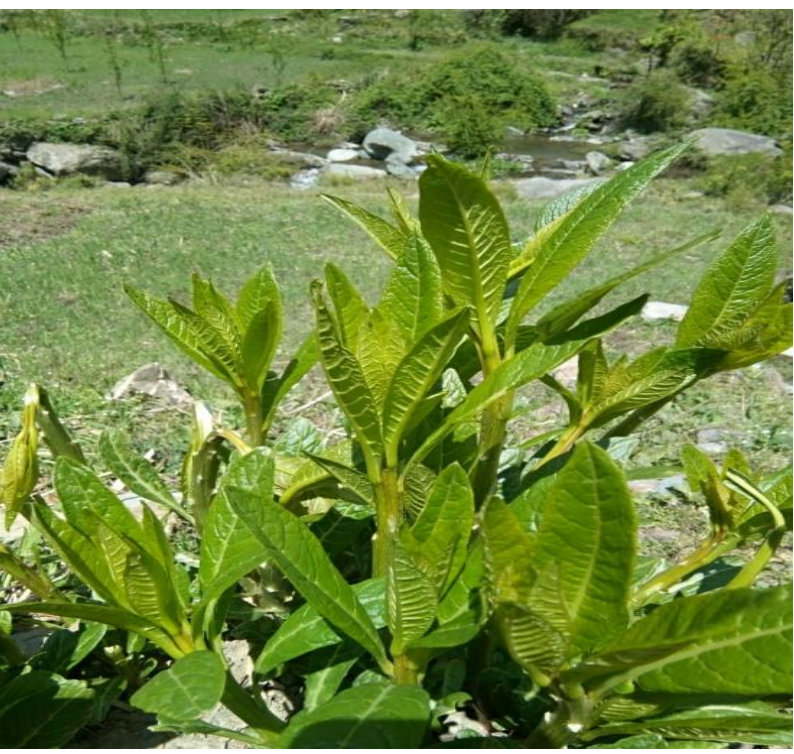

Phytolaca acinosa

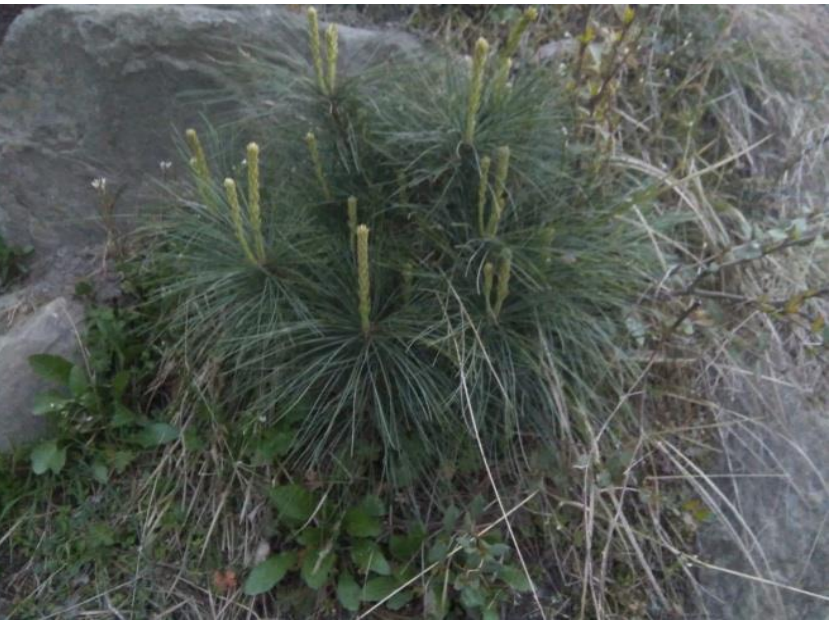

Pinus rouxburghi

Fig 1: Migratory shepherd and few medicinal plants used by them

\section{References}

1. Adhikari BS, Babu MM, Saklani PL, Rawat GS. Medicinal Plants Diversity and their Conservation Status in Wildlife Institute of India (WII) Campus, Dehradun, Ethnobotanical Leaflets. 2010; 14:46-83.

2. Anonymous. Management plan for Renuka Forest Division: 1999-2000 to 2013-2014. Working plan,
Sirmaur, (H.P.) Jain, SK (1991). Dictionary of Indian Folk Medicine and Ethnobotany. Deep Publication, New Delhi, 1999.

3. Arora A. Phytochemical Analysis of Methanolic Extracts of Leaves of Some Medicinal Plants. Biological ForumAn International Journal, 2013; 5(2):91-93. 
4. Bagga J, Umakant B, Deshmukh. Acmella radicans (Jacquin) R.K. Jansen (Asteraceae)-A new distributional plant record for Jharkhand State (India). Journal on New Biological Reports. 2018; 7(1):24-27.

5. Biswas MP, Rao MRM. Socioeconomic status of Gaddi tribes in Himachal Pradesh: a Study. International Journal of Advance Research. 2016; 4(8):159-167.

6. Charjan AP, Dabhadkar DK. Ethnomedicinal Documentation of Some Antidiabetic Plants used by Tribal's of Amravati District, Maharashtra. Biological Forum - An International Journal. 2014; 6(2):546-549.

7. Chowdhery HJ. Himachal Pradesh, in Mudgal V and Hajra P K(eds) Floristic diversity and conservation strategies in India in the context of state and union territories (BSI, Calcutta) 1999; II:845-94.

8. Dutt B, Nath D, Chauhan NS, Sharma KR, Sharma SS. Ethnomedicinal plant resources of Tribal Pangi Valley in District Chamba, Himachal Pradesh, India, International Journal of Bioresource and Stress Management. 2014; 5(3):416-421.

9. Rao KA, Rao KS, Rao SJ, Ravi A, Anitha A. Studies on migration of sheep flocks in north coastal zone of Andhra Pradesh: tribals of Chhitkul, Sangla valley, Ann of Plant Sci. 2011; 4(01):943-946.

10. Malik ZA, Bhat JA, Ballabha R, Bussmann RW, Bhatt BA. Ethnomedicinal plants traditionally used in health care practices by inhabitants of western Himalaya. J Ethnopharmacol. 2015; 172:133-44.

11. Kapoor G. Conservation and Development in Great Himalayan National Park-Western Himalaya. Journal on Biological Report. 2017; 6(3):142- 147. R

12. Sharma S, Rana M. Commonly used Medicinal Plants in Tehsil Pachhad District Sirmour, Himachal Pradesh; Pharma Tutor. 2016; 4(3):34-38.

13. Sharma V. Traditional Use of Ethnomedicinal Plants of Asteraceae in the Alpine Zone of Tungnath Region. International Journal of Theoretical \& Applied Sciences, 2016; 8(2):54-57.

14. Shiva MP. Inventory of forestry resources for sustainable management and biodiversity conservation. New Delhi: Indus Publishing Company, 1996.

15. Singh KNHP, Batish DR. Most prominent ethnomedicinal plants used by the tribals of Chhitkul, Sangla valley. Ann. of Plant Sci. 2015; 4(01):943-946.

16. Suresh A, Gupta DC, Mann JS. Trends, determinants and constraints of temporary sheep migration in Rajasthan-an economic analysis. Agri Economics Res Rev. 2011; 24:255-265.

17. Singh KNHP, Batish DR. Most prominent ethnomedicinal plants used by the tribals of Chhitkul, Sangla valley, Ann of Plant Sci. 2015; 4(01):943-946.

18. Verma RK, Kapoor KS. Status of Plant Diversity in Alpine Area of Rakchham- Chitkul Wildlife Sanctuary of District Kinnaur, Himachal Pradesh. Biological ForumAn International Journal. 2014; 6(1):5-12.

19. Yadav VK, Deoli J, Rawat L, Adhikari BS. Traditional Uses of Medicinal Tree Species in Renuka Forest Division, Western Himalaya. Asian Pac J Health Sci., 2014; 1(2):72-77. 